\title{
Ustroje kościołów ewangelicko-reformowanych w Rzeczypospolitej Obojga Narodów na przełomie XVI i XVII wieku
}

\section{W s tęp}

Wydana dwa lata temu edycja akt synodów Jednoty Litewskiej ${ }^{1}$ okazała się bodźcem do ciekawej i potrzebnej dyskusji na temat ustrojów polskich kościołów ewangelicko-reformowanych, w szczególności Jednoty Litewskiej². Pozwalam sobie włączyć się do tej dyskusji, gdyż, jak dotąd, brakuje w niej głosu ujmującego problem od strony prawa i teologii. Pozwoliłyby one, moim zdaniem, nie tylko uniknąć pewnych błędów, ale także, mam nadzieję, otworzyłyby nieco inną perspektywę, niż dotychczas obecna w tej dyskusji. Swoje uwagi chciałbym zacząć od generalnego przypomnienia znaczenia karności (dyscypliny) kościelnej dla ustroju kościołów reformowanych, a następnie przejść do omówienia dwóch modeli ustrojów, które wykształciły się w XVII w., by na koniec skoncentrować się na przypadku polskich prowincji kościelnych w wiekach XVI i XVII.

1 Por. Akta synodów prowincjonalnych Jednoty Litewskiej 1626-1637, oprac. M. Liedke, P. Guzowski, Wydawnictwo Naukowe Semper, Warszawa 2011, s. 211 (dalej jako: ASR V).

2 Por. M. Ptaszyński, O ustroju kościota. Uwagi na marginesie edycji „Akt synodów prowincjonalnych Jednoty Litewskiej 1626-1637”, OiRwP, 2012, 56, s. 203-226; M. Liedke, Struktura i kompetencje wtadz kościota ewangelicko-reformowanego w Wielkim Ksiestwie Litewskim $w$ XVI i XVII wieku na tle europejskim, w: Urzędy państwowe, organy samorzqdowe $i$ kościelne oraz ich kancelarie na polsko-ruskim pograniczu kulturowym i etnicznym w okresie od XV do XIX wieku, red. H. Gmiterek, J. Łosowski, Avalon, Kraków 2010, s. 347-366. 
2. Znaczenie karności (dyscypliny) kościelnej Teologia i eklezjologia ewangelicko-reformowana, wbrew spotykanym często w polskich źródłach tezom ${ }^{3}$, wymaga nie dwóch (jak w luteranizmie), ale trzech konstytutywnych elementów istnienia prawdziwego kościoła: głoszenia (zwiastowania) i słuchania Słowa Bożego, prawidłowego sprawowania sakramentów oraz dyscypliny (karności) kościelnej ${ }^{4}$. Na płaszczyźnie czysto symbolicznej widać to w XVI i XVII w. w kościołach reformowanych w Holandii i Szkocji, gdzie, oprócz ambony (symbolu i miejsca zwiastowania Słowa Bożego) oraz stojącego poniżej Stołu Pańskiego (symbolu i miejsca rozdawania Sakramentu Wieczerzy Pańskiej), po obu bokach ambony zawieszano tablice z Dekalogiem i słowami Modlitwy Pańskiej (Ojcze Nasz) jako symbolu i źródła dyscypliny kościelnej. Co ciekawe, mamy wzmianki o tym, że przynajmniej niektóre siedemnastowieczne kościoły ewangelicko-reformowane na Litwie miały podobny wystrój wnętrza, dając praktyczny wyraz głoszonej przez siebie teologii 5 .

Kształtowanie się dyscypliny kościelnej jako trzeciej przesłanki istnienia prawdziwego kościoła można zaobserwować już u Jana Kalwina. W swojej Institutio Christianae religionis pisał on (nawiązując do Lutra): „Kiedykolwiek zatem widzimy Słowo Boże czysto głoszone i słuchane oraz sakramenty sprawowane według ustanowienia Chrystusowego, tam, nie może to ulegać wątpliwości, istnieje Kościół Boży [...]. Albowiem Jego [Chrystusa] ${ }^{6}$ obietnica nie może zawieść: „Gdzie dwoje lub troje gromadzi się w moim imieniu, tam ja z nimi jestem” [...]. Jeśli zatem [Kościół] ma posługę Słowa Bożego i ją szan u je, jeśli udziela sakramentów, wówczas zasługuje on bez wątpienia na to, by być nazywanym i uważanym za Kościół”

W przeciwieństwie do Lutra, Kalwin nie poprzestał na tych dwóch przesłankach. Już słowa „i ją szanuje” sugerowały, że samo głoszenie Słowa

3 Por. M. Ptaszyński, op. cit., s. 205.

4 Por. J. H. Leith, Introduction to the Reformed Tradition, Westminster John Knox Press, Louisville London 1981, s. 145-148.

5 Por. B. J. K., Wspomnienia o Stucku, [b. wyd.], Gniezno 1905, s. 58-59.

6 Jeśli nie zaznaczono inaczej, wszystkie komentarze w cytowanych tekstach pochodzą od Autora artykułu [K. B.].

7 J. Calvin, Institutes of Christian Religion, ed. J. T. McNeill, Westminster John Knox Press, Louisville Kentucky 2006, s. 1023 (IV. I. 9). Wszystkie tłumaczenia tekstów angielskojęzycznych pochodzą od Autora artykułu [K. B.]. 
nie wystarcza. Tę myśl Kalwin rozwinął w tej samej, czwartej księdze Institutio, gdzie pisał o tym, dlaczego dyscyplina kościelna jest niezbędna dla istnienia prawdziwego kościoła: „Widzimy, że jakaś forma organizacji jest niezbędna w każdym ludzkim społeczeństwie, by popierać wspólny pokój i utrzymywać zgodę. Dalej, widzimy, że w relacjach międzyludzkich zawsze obowiązuje jakaś procedura, którą trzeba szanować dla utrzymania moralności publicznej, a nawet samej ludzkości. Ona winna być jeszcze bardziej przestrzegana w kościołach, które są w najlepszym stanie, gdy wszystkie [ich] sprawy są uregulowane dobrze ułożoną konstytucją, a które bez [takiej] zgody przestają być kościołami. Dlatego jeśli chcemy zapewnić bezpieczeństwo kościoła, musimy z całą powagą skupić się na Pawłowym przykazaniu, że „wszystkie sprawy muszą być dokonywane należycie i w odpowiednim porządku" (1 Kor 14, 40)"8.

Dla Kalwina dyscyplina kościelna, oparta na napominaniu w sferach prywatnej i publicznej wszystkich grzechów (mniejszych i większych, popełnionych jawnie i po kryjomu), była rzeczą absolutnie niezbędną. Jej celem było, po pierwsze, wykluczenie grzeszników, po drugie - ochrona wiernych kościoła przed zepsuciem, a po trzecie - wzbudzenie skruchy i nawrócenia (wskutek kar kościelnych) ${ }^{9}$.

Uczniowie Jana Kalwina bardzo szybko dostrzegli wagę tego aspektu jego nauczania, a karność kościelna stała się trzecim wyznacznikiem prawdziwego kościoła wśród reformowanych kościołów w Europie. Nie wymienia jej wprost Katechizm Heidelberski (1563), ale w pytaniach i odpowiedziach numer 54 i 55 zawarte są aluzje do zgodnego życia w kościele, co jest niemożliwe bez odpowiedniego urządzenia kościoła i dyscypliny kościelnej ${ }^{10}$. Karność kościelną jako jeden z trzech wyznaczników prawdziwego kościoła wyraźnie sformułowano w Konfesji Szkockiej (Scots Confession) w roku 1560. W Rozdziale XVIII: Znaki, po których Prawdziwy Kirk będzie rozpoznanym od Fatszywego, i kto powinien być sędzią doktryny czytamy: „Za wyróżniki, znaki i pewne wyznaczniki, dzięki którym niepokalana oblubienica Chrystusa jest odróżniona od obrzydliwej nierządnicy, fałszywego Kirku, uznajemy nie starożytność, uzurpowany tytuł, bezpośrednią sukcesję, stałą siedzibę ani liczbę mężczyzn aprobujących błędy [...]. Znakami prawdziwego Kirku,

8 Ibidem, s. 1205 (IV. X. 27).

9 Por. ibidem, s. 1229-1240 (IV. XII. 1-13); R. S. Paul, Freedom with order. The doctrine of the Church in the United Church of Christ, United Church Press, Cleveland Ohio 1987, s. 25.

10 Por. R. S. Paul, op. cit., s. 27-28. 
są, jak wierzymy, wyznajemy i uznajemy, najpierw, prawdziwe głoszenie Słowa Bożego [...], po drugie - prawdziwe sprawowanie sakramentów Chrystusa Jezusa [...] i - na koniec - kościelna dyscyplina sprawowana właściwie, jak nakazuje Słowo Boże, dzięki której występek jest niszczony, a cnota - pielęgnowana"11.

Znaczenie dyscypliny kościelnej jako warunku istnienia prawdziwego kościoła podchwyciła także Druga Konfesja Helwecka (1566) w rozdziale XVIII w sekcji pt. Dyscyplina (określona jako „absolutnie niezbędna dla kościoła") ${ }^{12}$, a także Confessio Belgica (1567) w artykule 29 Znaki Prawdziwego Kościota ${ }^{13}$. Do końca XVI w. jako niezbędny wyznacznik prawdziwego kościoła przyjęły ją praktycznie wszystkie kościoły reformowane w Europie. Angielska The Book of Discipline, ważna dla prac nad Westminsterskim Wyznaniem Wiary (1648), formułowała to dobitnie i bez wątpliwości: „Dyscyplina Kościoła Chrystusowego, która jest niezbędna w każdym czasie, jest przekazana przez Chrystusa i ugruntowana w Piśmie Świętym. Zatem prawdziwa i uprawniona dyscyplina, winna się stamtąd i tylko stamtąd wywodzić, zaś to, co się opiera na innych fundamentach, winno być uznane za bezprawne i [z prawem] sprzeczne" ${ }^{14}$.

Pogląd ten przejęli zarówno prezbiterianie w rozdziale XXII (O Karności kościelnej $)^{15}$ Westminsterskiego Wyznania Wiary, jak i angielscy kongregacjonaliści w punkcie IV Platformy Ustroju w Savoy $(1658)^{16}$.

Nie bez powodu poświęciłem tyle uwagi temu trzeciemu wyznacznikowi prawdziwego kościoła w teologii reformowanej: dążenie do wprowadzenia efektywnej dyscypliny kościelnej stało się od końca XVI po XVII w. nie tylko celem, ale i środkiem konfesjonalizacji w kalwińskich (reformowanych) państwach i regionach Europy ${ }^{17}$. I tak np. w Niderlandach wraz $\mathrm{z}$ umacnianiem się kalwinizmu jako religii publicznej zwiększał się nacisk na przestrzeganie kościelnej dyscypliny. Jednocześnie opór wobec karności

11 Book of Confessions. Study edition, Geneva Press, Louisville Kentucky 1999, s. 41-42. 12 Tekst Drugiej Konfesji Helweckiej znajduje się na stronie: http://www.reformed. org/documents/index.html (dostęp 17 V 2013).

13 Tekst Confessio Belgica znajduje się na stronie: http://www.reformed.org/documents/ index.html (dostęp 17 V 2013).

14 J. H. Leith, op. cit., s. 160.

15 Book of Confessions, s. 209-210.

16 Por. W. Walker, The creeds and platforms of Congregationalism, United Church Press, Cleveland Ohio 1991, s. 403.

17 Por. B. Arnold, Christ's churches purely reformed, Yale UP, New Haven-London 2002, s. 460-489. 
kościelnej w niektórych regionach (np. Utrecht czy Kampen w Overijssel) był formą sprzeciwu wobec doktrynalnego usztywniania się Holenderskiego Kościoła Reformowanego ${ }^{18}$. Ostatecznie spór ten rozstrzygnął się na płaszczyźnie sporu remonstrantów z kontrremonstrantami, a zwyciężyła w nim koncepcja stricte kalwinistyczna, podkreślająca znaczenie karności kościelnej ${ }^{19}$.

Podobne zjawisko obserwujemy także w Polsce, gdzie wraz z powolną, ale postępującą konsolidacją organizacyjną i teologiczną polskiego kalwinizmu coraz częściej pojawia się kwestia karności kościelnej. Synody Jednoty Małopolskiej zaczęły nie tylko zakazywać prywatnych ordynacji (na co słusznie zwraca uwagę Ptaszyński) ${ }^{20}$, ale również kłaść coraz większy nacisk na egzekwowanie dyscypliny kościelnej. Widać to nie tylko w zachowanych wizytacjach poszczególnych parafii, ale i w ponawianych przez synody dystryktowe wezwaniach do egzekwowania dyscypliny kościelnej. Na przykład synod dystryktu chęcińskiego w 1629 r. wyraźnie przypominał: „Dyscyplinę wedle nauki Pana Jezusowej, apostoła Św. Pawła przykładu i kanonów kościelnych do egzekucji przywodzić [mają], okrom żadnego respektu na osoby, tak ministrowie w swych zborach, jako też impp. seniorowie dystryktowi”"21.

Ptaszyński i Liedke słusznie zwracają uwagę, że ów wzmożony nacisk na kościelną dyscyplinę nie był, jak chciał Tazbir, przykładem „płytkości myśli reformacyjnej i powierzchownego charakteru polskiej reformacji”22. Wręcz przeciwnie, należałoby w tym raczej widzieć, wynikającą z postępującej konfesjonalizacji, konsolidację wyznaniową polskich reformowanych i ich dojrzałość teologiczną.

\section{Formy (typy) organizacji kościołów reformowanych}

Zagadnienie karności kościelnej jest ważne, gdyż wiązało się z kwestią organizacji kościelnej, tzn. z formą, jaką, według Kalwina i późniejszych

18 Por. K. Bem, Holenderski Kościót Reformowany w XVI i XVII wieku. Struktura, organizacja, problemy, OiRwP, 2005, 49, s. 63-92.

19 Por. K. Bem, Wilki i tagodne jagniątka Chrystusa. Powstanie, rozwój i rola Holenderskiego Kościota Reformowanego w XVI i XVII wieku, Wydawnictwo Naukowe Semper, Warszawa 2013, s. 90-98.

20 Por. M. Ptaszyński, op. cit., s. 210.

21 Akta synodów różnowierczych w Polsce, t. III: Matopolska 1571-1632, oprac. M. Sipayłło, PWN, Warszawa 1983, s. 530 (dalej jako: ASR III).

22 M. Ptaszyński, op. cit., s. 213. 
teologów reformowanych, winien przybrać „Kościół Chrystusowy prawdziwie reformowany”. Znów, rację mają zarówno Liedke, jak i Ptaszyński, wskazując, że ustrój wprowadzony przez Jana Kalwina w Genewie nie był nigdy uważany za jedynie słuszny, a już z całą pewnością nie przez samego Kalwina ${ }^{23}$. Wbrew krążącym opiniom o jego zacietrzewieniu i bezkompromisowości, Kalwin wykazywał zdumiewającą ustępliwość, gdy chodziło o organizację kościelną i jej formy. Choć w Genewie wprowadził formę prezbiteriańską, to jednocześnie wykazywał sporą elastyczność, gdy wymagały tego miejscowe warunki. I tak nie miał nic przeciwko zachowaniu biskupów w Kościele Anglii czy w Polsce, ale był już przeciwny ich istnieniu we Francji ${ }^{24}$. Mimo tego, że nie był szczególnym entuzjastą synodów, dopuszczał ich istnienie w Szkocji bądź Francji. Tę „elastyczność” rzadko popierali uczniowie Kalwina. Wraz z upływem czasu model genewski stał się powoli punktem odniesienia dla kościołów reformowanych na świecie, co nie oznacza, że był zawsze wiernie kopiowany. Należy o tym pamiętać szczególnie w kontekście tego, że w wielu miejscach zasięg oddziaływania kościołów reformowanych był dużo większy niż jedno miasto i jego najbliższe okolice, jak to było w przypadku Genewy, i stąd model genewski musiał ulegać modyfikacjom ${ }^{25}$.

Organizacja kościoła, według Jana Kalwina i innych teologów reformowanych, zakładała, co warto podkreślić, partycypowanie wiernych w wybieraniu starszych kościoła (świeckich i duchownych) i zarządzaniu kościołem oraz równość wszystkich starszych kościoła między duchownymi oraz między duchownymi a świeckimi. $Z$ tego powodu udział czynnika świeckiego w zarządzaniu kościołem nie „był administracją równoległą" ${ }^{26}$, a jej immanentną częścią.

Podkreślam to, polskojęzyczna literatura widzi bowiem zalążki systemu episkopalnego tam, gdzie tylko pojawia się termin „senior” albo „superintendent" ${ }^{27}$. Takie podejście może wynikać wyłącznie z niezrozumienia istoty reformowanej eklezjologii. System episkopalny, w którym biskup byłby osobnym urzędem albo miałby mieć osobną rangę i własne uprawnienia wynikające $\mathrm{z}$ tego urzędu, jest w sprzeczności z właściwym dla kalwinizmu założeniem o równości wszystkich duchownych. W Institutio

23 Por. M. Liedke, op. cit., s. 349.

24 Por. J. H. Leith, op. cit., s. 164-167.

25 Por. M. Liedke, op. cit., s. 349-353.

26 M. Ptaszyński, op. cit., s. 217.

27 Por. ibidem, s. 214-222. 
Kalwin wyraźnie podkreślał, że źródło władzy pierwszych biskupów płynęło z nadania i zgody wiernych i że biskupi podlegali opinii i władzy samych wiernych. W Komentarzu do Listu do Filipian, wyjaśniając słowo „biskup”, Kalwin pisze: „Biskupi. On [Apostoł Paweł] nazywa tak osobno pastorów z uwagi na szacunek. Co więcej, możemy z tego wywieść, że nazwa „biskup” oznacza wszystkich ministrów Słowa [Bożego], w takim zakresie w jakim przypisuje on kilku jednemu kościołowi. A zatem, biskup i pastor są synonimami. Potem nastał zwyczaj, że tylko ten, którego starsi kościoła (prezbitrzy) w każdym kościele wyznaczyli, by im przewodził, nazywał się biskupem. [...] Albowiem z zepsucia znaczenia [tego] słowa wyszło takie zło, jak gdyby wszyscy prezbitrzy nie byli kolegami, powołanymi do tego samego urzędu, a tylko jeden $\mathrm{z}$ nich, pod pretekstem nowej nazwy, uzurpował sobie zwierzchność nad innymi”"28.

Myśl tę jeszcze dobitniej sformułowano w Drugiej Konfesji Helweckiej, gdzie stwierdzono: „Zatem władzę albo funkcje, które są nadane pastorom Kościoła, są takie same i podobne we wszystkim"29. Podobnie stanowiła Konfesja Gallikańska: „Wierzymy, że wszyscy prawdziwi pasterze, gdziekolwiek by nie byli, mają tę samą władzę i autorytet pod tą samą głową, jedynym suwerenem i powszechnym biskupem, [którym jest] Jezus Chrystus. A zatem, żaden Kościół nie może żądać zwierzchności ani władzy nad innym"30.

Prawie identycznie powtórzyła tę myśl Confessio Belgica: „Jeśli zaś chodzi o Pasterzy Słowa Bożego, oni tak samo mają równą władzę i autorytet, gdziekolwiek by się nie znajdowali, jako że są ministrami Chrystusa, jedynego powszechnego biskupa, i Głowy Kościoła”1.

Początkowo w niektórych krajach (np. Szkocja, Węgry) na skutek różnych czynników reformowani eksperymentowali z funkcją - ale nie urzędem - biskupa, np. poprzez formułę biskupa wśród równych mu prezbitrów (Szkocja). Z czasem jednak, z kilkoma nielicznymi wyjątkami, system ten zdecydowanie zarzucono. W kościołach reformowanych, gdzie tę funkcję zachowano - zazwyczaj, co znamienne, używając nazwy „superintendenta” zamiast „biskupa” - podkreślano, że nie jest to osobny

28 Calvin commentaries: The Epistles of Paul the Apostle to the Galatians, Ephesians, Phillipians and Colossians, ed. D. W. Torrance, T. F. Torrance, Eerdmans, Grand Rapids 1966, s. 227.

29 Book of Confessions, s. 134.

30 J. H. Leith, op. cit., s. 163.

31 Ibidem. 
urząd kościelny, ale jedynie funkcja administracyjna powierzana jednemu z ministrów, prawie zawsze na określoną kadencję, a nie dożywotnio. I stąd choć np. w skandynawskim luteranizmie czy anglikanizmie można mówić o systemie episkopalnym, to rozciagganie tego określenia na kościoły reformowane tylko dlatego, że występuje tam „superintendent” lub „senior” jest nie tylko nieuprawnione, ale również prowadzi do pomieszania terminów eklezjologicznych i tworzenia zupełnie niepotrzebnych dziwolągów ustrojowych, jak „system episkopalno-synodalny”32.

Warto zauważyć, że w teologii i eklezjologii reformowanej nie istnieją „równoległe” administracje kościelne: duchowna i świecka. Zarząd nad kościołem sprawują prezbitrzy (starsi lub seniorzy): świeccy i duchowni ${ }^{33}$. Ordynowani są zarówno duchowni, jak i, co jest ewenementem w skali chrześcijaństwa, także świeccy! Żadna z trzech sfer kościelnych nie jest zarezerwowana wyłącznie dla prezbitrów świeckich albo wyłącznie duchownych. Chociaż głoszenie słowa i administracja sakramentów zazwyczaj leżała w gestii prezbitrów duchownych (czyli pastorów), to nawet i tam widać spore zaangażowanie świeckich (czytanie Pisma, asystowanie przy dystrybucji Wieczerzy Pańskiej, a nawet chrzcie; w tradycji reformowanej bez obecności świeckich prezbitrów chrzest nie może się odbyć).

Współdziałanie starszych (prezbitrów) świeckich i duchownych widać najlepiej właśnie w sferze karności kościelnej, gdzie pieczę nad jej wykonywaniem sprawowali wszyscy prezbitrzy: duchowni i świeccy, i to niezależnie od tego, czy podmiotem postępowania był duchowny czy świecki. W Szkocji dbanie o karność kościelną spoczywało w rękach najpierw rad parafialnych (kirk sessions), a następnie odpowiednikach genewskich konsystorzy, czyli prezbiteratów (presbyteries). W Niderlandach było podobnie - za karność kościelną odpowiadały rady parafialne (konsystorze), a następnie classis, składające się ze starszych (ouderlings). Paradoksalnie, przy całej swojej organizacyjnej i liturgicznej dysfunkcyjności małopolscy reformowani akurat tę cechę ustroju swojego kościoła rozumieli doskonale. To właśnie dlatego Andrzej Węgierski zauważył, że termin „senior” powinien się odnosić do członków „ordo equestris”. Tak samo wspomniany wyżej synod dystryktowy w 1629 r. przypomniał, że

32 M. Ptaszyński, op. cit., s. 222.

33 Zob. Cambridge Platform (Rozdziały VI, VII oraz Artykuły IX-XI Of The Institution of Churches and the Order Appointed in them by Jesus Christ, przyjęte przez Zgromadzenie Savoy). Szerzej o tym por. W. Walker, op. cit., s. 210-214, 404-405. 
za egzekwowanie dyscypliny kościelnej odpowiedzialni byli „zarówno tak ministrowie w swych zborach, jako też impp. seniorowie dystryktowi" ${ }^{34}$.

Kładąc zatem nacisk na prawidłowy i porządny ustrój kościoła oraz odrzucając zdecydowanie system episkopalny, gdzie biskup miałby osobne kompetencje i władzę wynikającą z własnego i odrębnego urzędu, kalwinizm albo ewangelicyzm reformowany stanął przed pytaniem: gdzie ulokowana jest - albo winna być - władza w kościele? Na przełomie XVI i XVII w. reformowani odpowiedzieli na ten dylemat w dwójnasób: w parafii ${ }^{35}$ (a zatem system kongregacjonalny) lub wśród prezbitrów, czyli starszych kościelnych (a zatem system prezbiterialny).

\subsection{Ustrój kongregacjonalny}

System kongregacjonalny pojawił się w połowie XVI w. we Francji, a jego ramy określił charyzmatyczny pastor Jean Morély, który sprzeciwiał się centralizacji francuskiego kalwinizmu na wzór genewski, co postulował Beza. Zdaniem Morély' ego, to parafia (kongregacja) winna wybierać pastora i starszych oraz egzekwować karność kościelną. Zanim zwolennicy Morély’ego zaczęli działać na dobre, zostali zgładzeni podczas Nocy Św. Bartłomieja i francuscy kalwiniści podążyli w kierunku modelu prezbiteriańskiego ${ }^{36}$.

Idee kongregacjonizmu odżyły u progu wieku XVII w Anglii. Tamtejsi kalwiniści niezadowoleni ze zbyt ospałej reformy Kościoła Anglii, żądali jego radykalnej przemiany poprzez uproszczenie liturgii, wzmocnienie dyscypliny kościelnej i zlikwidowanie funkcji biskupa ${ }^{37}$. Od około 1620 r. zaczęli emigrować do Nowej Anglii, gdzie przeprowadzili jeden z najbardziej radykalnych eksperymentów w historii chrześcijaństwa, a mianowicie ustanowili kongregacjonizm jako formę kościoła państwowego w koloniach: Massachusetts, Plymouth, Hartford, Connecticut

34 ASR III, s. 530.

35 Zamiast rozpowszechnionego w polskiej historiografii terminu „gmina” używam tutaj nazwy „parafia”, gdyż lepiej oddaje łacińskie słowo congregatio (zgromadzenie). Po drugie, słowo „parafia” trafniej określa sens i cel istnienia protestanckich kongregacji (zgromadzeń lub staropolskich „zborów”). Nie bez znaczenia jest również to, że w powszechnym języku protestancka „gmina”, w przeciwieństwie do rzymskokatolickich „parafii”, ma dużo bardziej deprecjonujący wydźwięk.

36 Por. R. M. Kingdon, Geneva and the consolidation of the French Protestant movement, 1564-1572, passim.

37 Por. W. Walker, op. cit., s. 1-27. 
oraz New Haven. Parafię powoływali sami wierni, którzy podpisywali przymierze (Covenant) regulujące sprawy wiary i organizacji parafii. $\mathrm{Na}$ stępnie wszyscy wierni, zjednoczeni tym przymierzem, wybierali starszych parafii i jej pastora. Była to ich suwerenna decyzja, niezależna od innych parafii (kongregacji) w okolicy. Te ostatnie służyły rada, ich delegaci (duchowni i świeccy) byli obecni przy ordynacji starszych i pastora, ale wszystkie decyzje podejmowali tylko i wyłącznie wierni danej i konkretnej parafii. Choć w wyborach najczęściej uczestniczyli mężczyźni, to znane są przypadki wczesnego udziału kobiet $\mathrm{w}$ tym procesie ${ }^{38}$. W przypadku braku jednomyślności, do której starano się dążyć, decydowała większość głosów, a mniejszość musiała się jej podporząakować. Dopiero od drugiej połowy XVII w. nastał zwyczaj pozwalania mniejszości na „wycofanie się" i założenie własnej parafii. Utrzymaniu jedności między parafiami służyły rady i spotkania duchownych (tzw. connection) oraz regularne zapraszanie duchownych okolicznych parafii, by głosili kazania u sąsiadów (tzw. pulpit exchange) ${ }^{39}$.

O tym, jak radykalnie przestrzegano systemu kongregacjonalnego, świadczy fakt, że w przypadku, gdy pastor przenosił się z jednej parafii do drugiej, musiał być ponownie ordynowany, gdyż ordynować mogła tylko parafia i tylko na swoje potrzeby ${ }^{40}$. I tak, kiedy pastor John Davenport (1597-1670) przeniósł się w 1668 r. z First Church w New Haven, gdzie był pastorem przez 30 lat, do parafii First Church w Bostonie, został ponownie ordynowany na pastora przez wiernych tej parafii ${ }^{41}$.

Naturalnie, taka radykalna niezależność każdej parafii musiała rodzić konflikty. Pierwszy z nich wybuchł w roku 1636, gdy oczytana i inteligentna Anne Hutchinson zaczęła głosić poglądy sprzeczne ze ścisłym kalwinizmem i znajdować posłuch wśród kolonistów. Władze kolonii zwołały pierwszy synod, który ją potępił i ustalił listę „błędów”. Ponieważ wszyscy pastorzy podzielali jego ustalenia, zwołanie innego ciała niż

38 W 1636 r. Hugh Peter, po wybraniu przez mężczyzn na pastora Angielskiego Kościoła Reformowanego w Rotterdamie, zażądał, aby zagłosowały także kobiety, co miało miejsce. Por. F. J. Bremer, Building a New Jerusalem. John Davenport, a Puritan in Three Worlds, Yale UP, New Haven-London 2012, s. 131-132.

39 Por. J. von Rohr, The shaping of American Congregationalism 1620-1957, Pilgrim Press, Cleveland Ohio 1992, s. 53-114.

40 Zwyczaj ten utrzymał się najdłużej, bo do schyłku XIX w., w Massachusetts.

41 Por. F. J. Bremer, op. cit., s. 333. 
kongregacja nie wzbudziło większych problemów ${ }^{42}$. Te pojawiły się 15 lat później, gdy część kongregacjonistów chciała poluzować zasady przyjmowania nowych członków do parafii oraz przepisy określające warunki chrzczenia dzieci. Tym razem zdania duchownych były podzielone i gdy władze kolonii zwołały w 1646 r. synod, wielu z nich zaprotestowało, twierdząc, iż idea synodu, zwoływanego przez świeckie władze, jest sprzeczna z systemem kongregacjonalnym. Dopiero gdy władze zmieniły listy zapraszające parafie na synod i zapewniły, że jego postanowienia będą miały wyłącznie moc doradczą dla poszczególnych parafii, synod mógł się wreszcie zebrać w Cambridge w roku 1647 . Jego prace przeciągnęły się do 1648 r. i zaowocowały tzw. Cambridge Platform. Uściśliła ona zasady członkostwa w parafiach, chrzczenia dzieci oraz potwierdziła teologiczne (ale nie eklezjologiczne) ustalenia Zgromadzenia Westminsterskiego w Londynie. Największym jej osiągnięciem było wypracowanie jasnych zasad ustroju kongregacjonalnego. Wzmocnieniu uległa także zasada niezależności i samorządności każdej parafii ${ }^{43}$.

O tym, jak wielką rangę miała parafia (kongregacja), świadczą zapisy Cambridge Platform: „Chociaż kościoły są różne, przez to nie mogą być ze sobą połączone; [są też] równe sobie, dlatego nie mają władzy nad sobą nawzajem, ale wszystkie kościoły winny utrzymywać kościelną komunię ze sobą, albowiem są zjednoczone wszystkie w Chrystusie, nie tylko mistycznie, ale w głowie [Kościoła]" ${ }^{44}$.

O synodach traktował rozdział XVI: „Przynależy synodom i radom debatować i roztrząsać kontrowersje wiary, sprawy sumienia [...] i dawać wskazówki co do ich reformowania. Ale nie sprawować karność kościelną jako dyscyplinę albo żaden inny akt władzy czy zwierzchności, czego się obecny synod trzymał" 45 .

Obradujący zaledwie 10 lat później synod angielskich kongregacjonistów w Savoy, na którym nie zabrakło pastorów z Nowej Anglii, zawarł podobne postanowienia w artykule XXVI: „W sprawach trudnych czy w kwestiach spornych, zarówno w odniesieniu do doktryny, jak i kwestii organizacji, [...] jest zgodne z zamysłem Chrystusa, by wiele kościołów w komunii razem, przez swoich wysłanników, spotkało się na synodzie albo radzie, by rozważyć i doradzać w sprawach spornych i by swą relację

42 Por. J. von Rohr, op. cit., s. 69-75.

43 Por. ibidem, s. 81-83; W. Walker, op. cit., s. 157-188.

44 J. von Rohr, op. cit., s. 229.

45 Ibidem, s. 233-234. 
zdać zainteresowanym kościołom. Jednakże tym synodom tak zebranym nie jest powierzona żadna władza kościelna, prawidłowo rozumiana, ani żadna zwierzchność nad samymi Kościołami, by sprawować karność kościelną ani nad Kościołami, ani nad osobami, ani by narzucać swoje ustalenia tym Kościołom czy starszym" ${ }^{46}$.

Kolejny synod w Nowej Anglii, zwołany w 1662 r., tym razem poważnie zmienił zasady udzielania chrztu niemowlętom, pozwalając na chrzest dzieci, których rodzice nie byli członkami kościoła, pod warunkiem, że było nim jedno z dziadków dziecka. I choć decyzję tę zaakceptowała większość synodałów, to większość parafii ustalenia synodu odrzuciła. W roku 1672, a więc dekadę później, nowe reguły przyjęło zaledwie 2/5 parafii kolonii. Wymownym przykładem jest parafia (kongregacja) First Church w Bostonie, w której budynku odbywał się synod w 1662 r. i której duchowni poparli postanowienia synodu. Pomimo tego, kongregacja ta do końca XVII w. odrzucała jego postanowienia ${ }^{47}$.

Podczas gdy niektóre parafie trzymały się sztywno starych reguł, inne szły w przeciwnym kierunku. W 1699 r. część mieszkańców Bostonu powołała nową parafię, Brattle Street Church, gdzie wyraźnie poluzowano wymogi wobec nowych członków i pozwolono kobietom na głosowanie we wszystkich sprawach kościelnych. Kiedy duchowni i parafie Bostonu odmówili pomocy przy ordynowaniu jej pierwszego pastora Benjamina Colemana, ten został ordynowany przez prezbiterian w Londynie. Pomimo początkowego oporu, dekadę później Brattle Street Church został uznany przez inne parafie Bostonu, a duchowni zaczęli wymieniać się w wygłaszaniu kazań z Colemanem. Znów zwyciężył kongregacjonizm ${ }^{48}$. Nie dziwi więc, że przy takim podejściu do pozycji synodów ich zwoływanie w Massachusetts przestało mieć większy sens - ostatni synod, tzw. Synod Reformujący (Reforming Synod), zebrał się w 1679 r. $^{49}$

Jedynym miejscem, gdzie tymczasowo udało się częściowo ograniczyć kongregacjonizm, była kolonia Connecticut. Tamtejsze władze kolonialne, kierowane nomen omen przez pastora, zwołały w 1708 r. synod do miejscowości Saybrook, gdzie duchowni i świeccy uchwalili tzw. Saybrook Platform, „by lepiej uregulować sprawowanie kościelnej dyscypliny”50.

46 Ibidem, s. 407.

47 Por. ibidem, s. 118-128.

48 Por. ibidem, s. 133-135; W. Walker, op. cit., s. 472-477.

49 J. von Rohr, op. cit., s. 124-128.

50 W. Walker, op. cit., s. 495-523. 
Na jej podstawie, choć zasadniczo zachowano niezależność każdej parafii, powołano nowe ciała: lokalne asocjacje ministrów (associations) oraz konsocjacje (consociations). Te pierwsze skupiały tylko i wyłącznie duchownych, miały się spotykać co najmniej dwa razy do roku i sprawować nadzór nad ortodoksyjnością duchownych oraz egzaminować kandydatów na pastorów. Jednak ograniczoną władzę dyscypliny kościelnej powierzono konsocjacjom. Składały się one z delegatów wszystkich parafii w danym regionie (po dwóch świeckich i jednym duchownym z każdej parafii). To one ordynowały nowych duchownych, przeprowadzały procesy dyscyplinujące duchownych i wiernych. Ich decyzje miały być wiążące dla wiernych i parafii, ale parafie musiały wcześniej wyrazić zgodę na przystąpienie do takich konsocjacji ${ }^{51}$. I choć zastrzeżono, że postanowienia Saybrook Platform mogą być wiążące tylko wobec tych parafii, które wyrażą na nie zgodę, to na skutek umiejętnej polityki kadrowej i edukacyjnej do końca XVIII w. przyjęła je większość parafii kongregacjonalnych w tej kolonii ${ }^{52}$.

System ten stał się na tyle atrakcyjny, że zaakceptowały go także kościoły w koloniach Vermont i (częściowo) New Hampshire ${ }^{53}$. W początkowym okresie wzorowali się na nim również prezbiterianie w koloniach Pennsylvania, New Jersey i New York ${ }^{54}$. Ten „częściowy prezbiterianizm” okazał się u progu XIX w. niezwykle skuteczny w rywalizacji z unitarianizmem. Podczas gdy stany Connecticut i Vermont pozostały prawie nietknięte schizmą unitariańską, w Massachusetts, gdzie brakowało podobnych elementów kontroli ortodoksji duchownych i parafii, ponad 126 parafii reformowanych, w tym prawie wszystkie w Bostonie, ostatecznie opowiedziało się za unitarianizmem ${ }^{55}$.

\subsection{Ustrój prezbiterián ski}

System kongregacjonalny, gdzie cała władza spoczywała tylko i wyłącznie w rękach parafii, pozostał fascynującym, ale, mimo wszystko, wyjątkiem

51 Por. ibidem, s. 503-506.

52 Por. J. von Rohr, op. cit., s. 157-160; W. Walker, op. cit., s. 507-513; C. B. Cowing, The saving remnant. Religion and the setting of New England, University of Illinois Press, Chicago 1995, s. 267-296.

53 Por. J. von Rohr, op. cit., s. 206-208.

54 Por. B. J. Longfield, Presbyterians and the American culture. A history, Westminster John Knox Press, Louisville Kentucky 2013, s. 1-7.

55 J. von Rohr, op. cit., s. 251-254. 
w kalwinizmie XVI i XVII w. Od połowy XVI w. większość kościołów reformowanych zmierzała w kierunku prezbiteriańskim, polegającym na tym, że władzę w kościele sprawowali wybierani - w sposób mniej lub bardziej demokratyczny przez wiernych - prezbitrzy, czyli starsi (elders, seniorzy, ouderlingen itd.). O dyscyplinę kościelną dbano od najbardziej podstawowego poziomu - parafii (rada parafialna, konsystorz parafialny), a potem $-\mathrm{w}$ ciałach nadzorczych: genewskim konsystorzu, szkockim prezbiteriacie, holenderskiej classis. Jak wspomniano wyżej, organy te tworzyli zarówno duchowni, jak i świeccy, i wszyscy formalnie byli sobie równi, chociaż mieli różne zadania ${ }^{56}$.

Co znamienne, większość uczniów Kalwina nie miała takich jak on zastrzeżeń wobec istnienia synodów ${ }^{57}$. W różnej formie zaczęły się one pojawiać w kościołach Szkocji (Zgromadzenie Generalne), Francji (Synod Narodowy), Holandii (Synody Prowincjonalne) i na Węgrzech - a więc tam, gdzie zasięg kościołów reformowanych był większy niż jedno miasto i gdzie w związku z tym należało mniej lub bardziej zmodyfikować model genewski.

W przeciwieństwie do kongregacjonizmu decyzje synodów w systemie prezbiteriańskim miały moc wiążącą. Trzeba jednak wyraźnie podkreślić, że synody nie były w żadnym wypadku osobnym urzędem czy źródłem władzy kościelnej. Ich ranga i moc stanowienia prawa wynikały tylko i wyłącznie z tego, że były one zgromadzeniem wszystkich albo większości starszych (prezbitrów) Kościoła w danym państwie czy prowincji, odpowiadających za karność kościelną i zarządzanie. Stąd owa wiążąca moc ich postanowień zarówno w formie decyzji prawodawczych, jak i sądowych. W 1645 r. tę zasadę wyłożyło krótko i dobitnie szkockie Zgromadzenie Generalne: „Pismo uznaje innego rodzaju zgromadzenia dla zarządzania kościołem oprócz tego związanego z classis czy kongregacjonalnego, które my nazywamy synodalnym.

Pastorzy i nauczyciele oraz inni zarządzający kościołem (a także i inne godne tego osoby, jeśli jest to pożądane) są członkami takich zgromadzeń, które my nazywamy synodalnymi wtedy, jeśli są właściwie do nich powołani.

$\mathrm{Z}$ prawnego punktu widzenia synody mogą być: prowincjonalne, narodowe i ekumeniczne" 58 .

56 Por. J. H. Leith, op. cit., s. 155-164.

57 Zob. np. Rozdział XXXIII Westminsterskiego Wyznania Wiary, w: Book of Confessions, s. 210-211.

58 Zob. na: http://www.reformed.org/documents/wcf_standards/index.html. 
A zatem, synody nie miały władzy ani autorytetu z racji bycia synodem (podobnie jak biskupi), ale raczej z faktu bycia zgromadzeniem starszych (prezbitrów) kościoła. Stąd Kościoła Szkockiego w Szkocji czy Holenderskiego Kościoła Reformowanego, chociaż znały instytucje corocznego Zgromadzenia Generalnego (Szkocja) czy synodów prowincjonalnych (Niderlandy), nie sposób określić mianem kościołów synodalno-prezbiterialnych, gdyż jest to teologiczne i prawne nieporozumienie. Są to kościoły klasycznie prezbiteriańskie - władzę w nich sprawowali starsi (prezbitrzy) i tylko starsi na różnych szczeblach organizacji kościelnej (parafialnym, prezbiterialnym czy synodalnym).

4. Ustroje kościołów reformowanych

w Rzeczypospolitej

Uwzględniając powyższe rozważania, należy przyjrzeć się polskim prowincjom protestanckim w Wielkopolsce, Małopolsce i Wielkim Księstwie Litewskim oraz zobaczyć, czy rzeczywiście ich organizacje były na tyle unikalne w skali Europy, by ich ustrój określać jako: „ustrój synodalno-prezbiterialny" ${ }^{\prime 9}$ albo „synodalno-episkopalny” ${ }^{60}$.

\subsection{Jednota Wielkopolska (Braci Czeskich)}

Jednota Braci Czeskich, która rozwinęła się w drugiej połowie XVI w. w Wielkopolsce, bywa często zaliczana do jednej z trzech prowincji małopolskiego kalwinizmu. Jest to o tyle problematyczne, że był to organizm kościelny początkowo zachowujący znamienny dystans zarówno wobec luteranów, jak i reformowanych, i to nie tylko w Rzeczypospolitej ${ }^{61}$.

Założona jeszcze w XV w. w toku walk husyckich i pozostająca poza czeskim pokojem religijnym Jednota zachowała swój specyficzny ustrój, zwyczaje kościelne oraz liturgię w chwili przybycia na teren Wielkopolski ok. roku $1548^{62}$. Jednota miała złożoną hierarchię duchowieństwa, a na

59 Za pojawienie się tego terminu odpowiada, jak się zdaje, A. Woyde (1860-1925), który wydając w 1915 r. akta synodów litewskich, po raz pierwszy użył tego zwrotu, który od tej pory funkcjonuje w polskiej historiografii. Por. Akta synodów prowincjonalnych Jednoty Litewskiej 1611-1625, „Monumenta Reformationis Polonicae et Lithuanicae”, S. IV, z. II, [b. wyd.], Wilno 1915, s. VIII-IX (dalej jako: SJL).

60 Por. M. Ptaszyński, op. cit., s. 214-222.

61 Por. ibidem, s. 206-208.

62 Por. J. Dworzaczkowa, Bracia czescy w Wielkopolsce w XVI i XVII wieku, Wydawnictwo Naukowe Semper, Warszawa 1997. 
jej czele stali seniorzy duchowni zwani w Czechach biskupami, choć w Polsce przyjęło się ich nazywać seniorami. W sprawach ogólnokościelnych zbierano się na synodach, w których, co było ewenementem, uczestniczyli wyłącznie duchowni. Co więcej, choć na owych synodach obecni byli wszyscy duchowni, to decyzje podejmowali biskupi (seniorzy) i ich zastępcy, zwani konseniorami. Ich wyboru dokonywano poprzez tajne głosowanie na kartkach, ordynowano zaś na urząd poprzez nałożenie rąk. Dla tego urzędu bardzo ważna była sukcesja biskupia, gdyż biskupi ordynowali kandydatów na duchownych. Z pośredniej wzmianki wynika, że przynajmniej w ordynacji na diakona uczestniczyli także zwykli księża Jednoty ${ }^{63}$. Od 1557 do 1608 r. na terenie Wielkopolski działał jeden senior mający zazwyczaj dwóch lub trzech konseniorów do pomocy, a świeccy byli wykluczeni z podejmowania decyzji kościelnych. $\mathrm{Z}$ tych względów można określić ustrój Jednoty jako episkopalny, co czyniło go wyjątkowym na tle ustrojów polskich - i nie tylko - kościołów ewangelickich.

Oczywiście, wraz z upływem czasu i koniecznością adaptacji do polskich potrzeb, ewoluowały doktryna, liturgia i - w końcu - ustrój Jednoty. Pierwsza zmiana wiązała się ze zniesieniem obowiązkowego celibatu wśród księży i seniorów (1579) i okazała się wówczas na tyle rewolucyjna, że pierwszy senior (biskup) Jednoty w Wielkopolsce Jan Rokyta (od 1557 r.) oburzony powrócił do Czech (1580). Jego następcami byli w latach 1571-1587 Jan Lorenc, sprawca owego „skandalu”, oraz w latach 1587-1608 Symeon Turnowski ${ }^{64}$. Pod ich prężną, ale i ciężką ręką liczba wiernych powiększyła się, a sama Jednota utrzymała odrębność liturgiczną oraz, co ważne, starała się zachować dystans zarówno wobec luteranów, jak i kalwinistów. $\mathrm{O}$ tych różnicach wspominano wyraźnie podczas synodu w Poznaniu (1580) ${ }^{65}$ i Bolesławiu (1598), gdzie podkreślano różnice między Jednotą a kalwinistami ${ }^{66}$.

Biskup Symeon Turnowski był szczególnie sumienny w utrzymywaniu i pielęgnowaniu odrębności Jednoty w szczególności wobec kalwinistów, co mogło być spowodowane jego studiami teologicznymi w Wittenberdze.

63 Por. Akta synodów różnowierczych w Polsce, t. IV: Wielkopolska 1569-1632, oprac.

M. Sipayłł, Wydawnictwa UW, Warszawa 1997, s. 366 (dalej jako: ASR IV).

64 Por. ibidem, s. 426, 438, 445.

65 Por. ibidem, s. 68.

66 Por. ibidem, s. 147. 
Latami blokował on nie tylko zmiany liturgiczne ${ }^{67}$, ale także skutecznie torpedował postulaty, by do rządów w Jednocie dopuścić świeckich patronów. Ci ostatni odgrywali w ustroju Jednoty rolę znikomą, szczególnie że w Czechach byli nimi głównie chłopi i ubodzy mieszczanie. W Rzeczypospolitej, gdzie Jednota zależała od zamożnych i wpływowych patronów szlacheckich, jak Krotoscy, Leszczyńscy czy Ostrorogowie, pozycja świeckich w Jednocie musiała ulec zmianie. Był to jednak proces długi i żmudny.

W 1573 r. powołano szumnie świeckich seniorów dla sześciu dystryktów Jednoty. Jednak, co znamienne, w przeciwieństwie do seniorów duchownych seniorzy świeccy nie zostali ordynowani, a jedynie wprowadzeni w urząd i to poprzez podanie dłoni - a nie przez nałożenie rą ${ }^{68}$. Nic więcej o ich działalności nie słychać. W 1579 r. pozwolono świeckim seniorom tylko asystować przy wizytacji przez biskupa parafii, przyznając przy tym wyraźnie, że jest to w Jednocie novum $^{69}$. Nic dziwnego, że w 1582 r. duchowni seniorzy Jednoty stwierdzili: „Około powinności świeckich senijorów, eksperyjencja pokazuje, że trudno, abyśmy ich mieli pożytecznie użyć ku czynieniu rządu"70. Konsekwencją tego poglądu było zaniechanie angażowania świeckich seniorów w sprawy Jednoty. W 1602 r. podczas synodu w Koźminku, zapewne na skutek nacisku wiernych, biskupi odpowiedzieli dwuznacznym postanowieniem: „Synodowi panów patronów barzo byśmy i my wszystcy radzi, a konferować o tym i naradzać się z pany patronami będziemy. Patronowi, chcącemu na naszy synod przyjechać, zawżdy wolność była i jest"71.

Świeccy patroni chyba nie do końca w tę „radość” i „wolność” wierzyli, bo synody nadal odbywały się tylko wśród księży, a decyzje dalej podejmowali tylko senior i konseniorzy.

O roli biskupa Turnowskiego i jego autorytetu w trzymaniu się tego konserwatywnego poglądu świadczyć może fakt, że po jego śmierci kilka nierozwiązanych dotąd spraw nagle ruszyło z miejsca. Chodzi tutaj nie tylko o rozwiązanie niektórych problemów liturgicznych, ale także

67 Por. K. Bem, "From many different sources”: The formation of the Polish and Lithuanian Reformed liturgy, w: T. Berger, Liturgy in migration. From the Upper Room to Cyberspace, Liturgical Press, Collegeville 2012, s. 115-119.

68 Por. ASR IV, s. 27-28.

69 Por. ibidem, s. 60.

70 Ibidem, s. 83.

71 Ibidem, s. 174. 
o większą demokratyzację władzy w kościele i kwestię udziału świeckich. Najpierw wybrano dwóch seniorów duchownych, co stało się odtąd praktyką Jednoty i było drobnym, ale wymownym krokiem na rzecz demokratyzacji władzy w kościele ${ }^{72}$. Na majowym synodzie w Ostrorogu w 1609 r. postanowiono zwołać nowy synod do Poznania, w którym mieli wziąć udział świeccy - absolutna nowość w historii Jednoty ${ }^{73}$. Rzeczywiście, na zebranym miesiąc później synodzie - określonym wprost jako „synod szlachecki” - nie tylko wybrano po raz pierwszy od $1583 \mathrm{r}$. seniorów świeckich, ale także ordynowano ich na ten urząd na wzór małopolski i ustalono dużo dokładniej ich kompetencje ${ }^{74}$. Jednota Braci Czeskich zaczęła powoli, ale nieubłaganie zmierzać w stronę kalwinizmu.

Ów trend, dotychczas mylnie określany w polskiej historiografii jako „irenizm”, był raczej przykładem postępującej konfesjonalizacji Braci Czeskich w kierunku wyraźnie reformowanym. Czynniki przyspieszające ten proces były wielorakie i skomplikowane: po Turnowskim wszyscy seniorzy studiowali już na kalwińskich uniwersytetach, wielu duchownych Jednoty służyło w zborach kalwińskiej Jednoty Małopolskiej na Rusi, Lubelszczyźnie i Wołyniu. Ważnym czynnikiem był wreszcie fakt, że Jednota Braci Czeskich nie wypracowała własnego oficjalnego tłumaczenia liturgii w języku polskim, dlatego część duchownych korzystała z małopolskiej Agendy z roku 1611. Wybór byłego superintendenta kalwinistów kujawskich, Daniela Mikołajewskiego, na jednego z dwóch seniorów Jednoty w 1627 r. był raczej symbolem zachodzących zmian niż znakiem konfesyjnej rewolucji ${ }^{75}$.

Dostrzegając zachodzące zmiany, powinniśmy być bardzo ostrożni w ich ocenie. Nawet po synodzie szlacheckim w 1609 r. początkowo udział świeckich nie poraża gorliwością. Dzięki temu seniorom duchownym udało się de facto zachować ustrój episkopalny jeszcze przez 40 lat. Jednak raz wypuszczonego dżina z butelki nie dało się wsadzić do niej z powrotem. W 1627 r. użyto po raz pierwszy w aktach synodu terminu „konsystorz" ${ }^{\text {"76 }}$ na określenie zebrania ówczesnych seniorów i konseniorów (w 1627 r. w Jednocie pracowało dwóch seniorów i siedmiu konseniorów, z czego aż pięciu wybrano i ordynowano na synodzie w 1627 r.). Fakt, że

72 Por. ibidem, s. 187-188.

73 Por. ibidem, s. 199-202.

74 Por. ibidem, s. 203-208.

75 Por. K. Bem, From many different sources, s. 115-119.

76 ASR IV, s. 310. 
akurat także na tym właśnie synodzie sfinalizowano unię z kujawskimi kalwinistami, nie jest, moim zdaniem, przypadkowy ${ }^{77}$.

Ostatecznie na skutek postanowień synodu we Włodawie Jednota Braci Czeskich nie tylko przyjęła (z pewnym marginesem swobody) wspólną dla małopolskich i litewskich reformowanych liturgię, ale zaczęła coraz bardziej upodabniać się do nich pod względem ustroju ${ }^{78}$. W 1637 r. ustalono, że oprócz duchownych na synod powinno przybywać dwóch patronów świeckich z każdej parafii. W 1654 r. wreszcie powołano do zarządu Jednotą stałych seniorów świeckich. Nieprzypadkowo, według mnie, odbyło się to wtedy, gdy jednym z dwóch seniorów był wywodzący się z Małopolski Jan Bythner Młodszy (zm. 1671) ${ }^{79}$.

Konkludując, Jednota Braci Czeskich, jako kościół pozostający pomiędzy luteranizmem a kalwinizmem, zachowała także do początku XVII w. swój unikalny, tzn. episkopalny, ustrój kościelny. Jednak od końca XVII w. można zaobserwować nie tylko postępującą kalwinizację tej Jednoty, ale także osłabienie jej systemu episkopalnego na rzecz prezbiterianizmu, który to proces ulega wyraźnemu przyspieszeniu po roku 1608 . Zakończył się on dopiero w połowie XVII w., choć pewne relikty systemu episkopalnego (np. ordynacja poprzez nakładanie rąk, kwestia sukcesji apostolskiej) przetrwały w strukturze Jednoty do początków XIX w. ${ }^{80}$

\subsection{Jednota Małopolska}

Ustrój Jednoty Małopolskiej trudno przed 1595 r. nazwać inaczej niż „przypadkowym kongregacjonizmem”, a to i tak przyjmując, że można traktować wszystkie zbory w Małopolsce, na Wołyniu, Rusi i Lubelszczyźnie jako jeden organizm kościelny. Przed tą datą większość parafii powstawała pod wpływem mniejszej lub większej gorliwości patrona i, oprócz gotowości do odrzucenia form rzymskokatolickich, często łączyło je niewiele więcej zarówno na płaszczyźnie teologicznej, jak i eklezjologicznej

77 Uczynili to seniorzy: Daniel Mikołajewski (kalwinista z Kujaw) i Marcin Gertych oraz konseniorzy: Jan Turnowski Mł., Paweł Paliurus, Marcin Orminius, Jan Rybiński Mł., Jakub Memorat, Marcin Giertych mł., Jakub Gembicki (kalwinista z Kujaw). Por. ibidem, s. 310 .

78 Por. K. Bem, From many different sources, s. 123-130.

79 Por. M. Pawelec, Barttomiej Bythner starszy (ok. 1559-1629), Wydawnictwo Naukowe Semper, Warszawa 2008, s. 92-93; J. Dworzaczkowa, op. cit., s. 120.

80 Por. O. Kiec, Protestantyzm w Poznańskiem 1815-1918, Wydawnictwo Naukowe Semper, Warszawa 2001, s. 105-118. 
czy liturgicznej. Na wspólną liturgię kościoły w Małopolsce musiały czekać aż początku XVII w. ${ }^{81}$ Kulała również wspólna organizacja kościelna. Przypomnijmy, że mimo powtarzanych prób uporządkowania kościoła w 1560, 1561 oraz 1570 r., na ostateczną organizację, obejmującą w zasadzie całość ziem Małopolski, Lubelszczyzny, Rusi, Wołynia oraz Zatoru Oświęcimia, przyszło czekać do 1599 r., ale tak naprawdę proces ten zakończono dopiero w $1620 \mathrm{r}^{82}$ Jednak nawet i po tej dacie wciąż zdarzały się parafie i patroni funkcjonujący poza oficjalną strukturą kościelną: jeszcze w 1632 r. synod dystryktowy w Okszy skarżył się na pastora i zbór w Sobkowie, wzywając go „do jednoty z nami” ${ }^{83}$. Zdaje się, że zarówno ów zbór, jak i jego patroni nie mieli bliższych kontaktów z Jednotą Małopolską od przeszło 30 lat! Podobne sytuacje miały miejsce w kilku innych zborach na terenie Małopolski (Goźlice, Rymanów, Chrząstów, Kossów, Niszczyce itd.).

Piszę o latach ok. 1550-1595 jako o „przypadkowym kongregacjonizmie”, gdyż w większości zborów decyzje podejmowano na szczeblu lokalnym, tzn. parafialnym. Wyjątkiem był pozostający na uboczu małopolskiej organizacji kościelnej dystrykt lubelski, gdzie bardzo szybko pojawiły się zalążki prężnej organizacji kościelnej. Co znamienne, dystrykt ten przodował także pod kątem uniformizacji liturgii reformowanej ${ }^{84}$. W pozostałej części Małopolski panował „przypadkowy kongregacjonizm”, gdyż nie wynikał on z głębszej refleksji teologicznej, ale raczej ze specyfiki warunków lokalnych.

O tym, że wierni chcieli jakiejś lepszej i efektywniejszej organizacji kościelnej, świadczy zwrócenie się części małopolskich reformowanych do braci czeskich i wybór Feliksa Crucigera na superintendenta nowego kościoła na synodzie w Słomnikach w $1554 \mathrm{r}^{85}$ oraz dodanie mu trzech konseniorów (na wzór ustroju braci czeskich) na synodzie w Secyminie w 1556 r. ${ }^{86}$ Kiedy jednak dyscyplina i ustrój braci czeskich przestały się podobać Małopolanom, zwrócili się oni w kierunku szwajcarskim: już

81 Por. K. Bem, From many different sources, s. 101-115.

82 Por. S. Tworek, $Z$ zagadnień organizacji zborów kalwińskich $w$ Matopolsce $w$ XVI-XVII w., „Rocznik Lubelski” 1965, 8, s. 63-75.

83 ASR III, s. 574.

84 K. Bem, From many different sources, s. 109-112.

85 Por. Akta synodów różnowierczych w Polsce, t. I: 1550-1559, oprac. M. Sipayłł, Wydawnictwa UW, Warszawa 1968, s. 4 (dalej jako: $A S R$ I).

86 Por. ibidem, s. 46-52. 
podczas synodu w Pińczowie w 1556 r. seniorom dobrano świeckich patronów, nazwanych wtedy jeszcze „diakonami” ${ }^{7}$. Definitywne odrzucenie modelu kościoła episkopalnego na wzór braci czeskich nastąpiło podczas sierpniowego synodu w 1557 r. w Pińczowie, gdzie wybrano sześciu świeckich seniorów, zdefiniowano wyraźnie kompetencje diakonów, powołano namiastkę konsystorza w postaci „konwokacji seniorów”88. Małopolscy reformowani, a przynajmniej ich bardziej świadoma i aktywna kościelnie część zaczęła zmierzać w kierunku prezbiterianizmu.

Dla niektórych badaczy argumentem na rzecz systemu episkopalnego ma być powołanie i istnienie urzędu superintendenta generalnego sprawowanego przez Feliksa Crucigera w latach 1554-1561. Moim zdaniem, wynika to ze zbytniego przywiązania do nazwy „superintendent generalny”, a nie z analizy faktycznego funkcjonowania tego stanowiska. Już sam fakt, że od początku istnienia tej funkcji (od 1554 r.), miała ona określoną kadencję (jeden rok), nakazuje zachować ostrożność w przypisywaniu jej zbytniej wagi, a tym bardziej - rangi biskupa. O rzeczywistym i znikomym znaczeniu stanowiska świadczy chociażby opis wizyty braci czeskich w Secyminie, gdy małopolscy ministrowie, znużeni łajaniami tych pierwszych, zwyczajnie uciekli na zamek do Stanisława Szafrańca, niewiele sobie robiąc z samego superintendenta generalnego, którego zostawili na pastwę uciążliwych gości ${ }^{89}$. O tym, że funkcji tej nie traktowano jako osobnego urzędu i powoli ewoluował on w kierunku prezbiteriańskim, świadczy fakt wybrania w 1560 r. jako pomocników dla superintendenta generalnego, oprócz sześciu seniorów świeckich, dwóch duchownych nazwanych seniorami (Franciszka Lismanina i Jerzego Blandratę) oraz zastrzeżenie, iż wszystkie te funkcje mają być sprawowane tylko przez rok $^{90}$. W $1561 \mathrm{r}$. Cucigera nie wybrano ponownie i na stanowisku superintendenta generalnego zastąpił go Stanisław Lutomirski, zięć Łaskiego ${ }^{91}$. Gdy po 1562 r. Lutomirski, Cruciger i Blandrata opowiedzieli się za arianizmem, stanowisko superintendenta generalnego zwyczajnie w kościele małopolskim zaniknęło aż do roku 1595. W tym samym okresie dawni seniorzy dystryktowi zaczęli być tytułowani superintendentami.

87 Ibidem, s. 53-58.

88 Por. ibidem, s. 219-239.

89 Por. ibidem, s. 84-94.

90 Akta synodów różnowierczych w Polsce, t. II: 1560-1570, oprac. M. Sipayłł, Wydawnictwa UW, Warszawa 1972, s. 32-68 (dalej jako: ASR II).

91 Por. ibidem, s. 77, 91. 
To tłumaczy pewien chaos terminologiczny, na który zwrócił uwagę, ale błędnie zinterpretował, Ptaszyński ${ }^{22}$. W rzeczywistości Jednota Małopolska zaczęła wtedy przypominać Jednotę Litewską, która, choć posiadała superintendentów dystryktowych, nie miała funkcji superintendenta generalnego. Występowanie funkcji i nazwy superintendenta czy to na poziomie dystryktów, czy kościołów, nie świadczy w żaden sposób o ustroju episkopalnym, a już z całą pewnością nie w Małopolsce ${ }^{93}$.

Lata 1562-1570 są okresem, gdy ledwo ukształtowana organizacja kościoła małopolskiego znowu uległa rozkładowi. Pewna poprawa nastąpiła po 1570 r., od kiedy zaczęły zbierać się synody dystryktowe i z pomocą zdeterminowanych patronów świeckich oraz energicznego Pawła Gilowskiego (jako superintendenta dystryktu krakowskiego) próbowały zapanowywać nad chaosem. Już w 1573 r. zalecono wiernym parafii w Krakowie: „Aby wszyscy disciplinam z pilnością chowali i rozpustnych i swawolnych między sobą nie cierpieli [...] ale takowych na synodzie publico okazali, a ku karaniu i ekskomunikacji dali"94.

Proces rekonsolidacji małopolskiego kalwinizmu trwał jednak długo. Podczas synodu generalnego w Piotrkowie w 1578 r. zabroniono prywatnych ordynacji oraz nakazano egzekwowanie dyscypliny kościelnej ${ }^{95}$, w Wodzisławiu w 1583 r. wprowadzono cenzurę kościelną i ponowiono nakaz egzekwowania dyscypliny kościelnej ${ }^{96}$. Znów zaczęto zwoływać regularnie synody prowincjonalne (w 1589 r. we Włodzisławiu) i dystryktowe ${ }^{97}$.

Rzeczywista konsolidacja organizacyjna małopolskiego kalwinizmu przyspieszyła wyraźnie pod wpływem synodu toruńskiego w 1595 r. I tak w 1595 r. wybrano pierwszego od 1561 r. superintendenta generalnego Franciszka Jezerskiego $^{98}$, a w 1608 r. - energicznego Franciszka Stancara

92 Por. M. Ptaszyński, op. cit., s. 215-216.

93 Por. ibidem, s. 216.

94 Kronika zboru ewangelickiego krakowskiego przez x. Wojciecha Węierskiego, red.

M. Pawelec, Parafia Ewangelicka w Krakowie, Kraków 2007, s. 73.

95 Por. ASR III, s. 40-41.

96 Por. ibidem, s. 75-84.

97 Por. ibidem, s. 96-100. Zdaje się, że w latach 1565-1595 jedynym dystryktem, który działał bez większych przerw, był dystrykt lubelski, pozostający jednak, co znamienne, poza pierwotną organizacją kościelną Małopolski.

98 Por. ASR III, s. 173; L. Szczucki, Franciszek Jezerski (zm. ok. 1616/1617), w: PSB, t. $11(1964 / 1965)$, s. 200. 
Młodszego 99 . W 1599 r., jak już wspomniałem, dokonano kolejnej, skuteczniejszej reorganizacji kościoła małopolskiego. W tym samym okresie rozpoczął się tam również proces unifikacji liturgicznej ${ }^{100}$. Moim zdaniem, wszystkie te zmiany zachodzące w łonie Jednoty Małopolskiej należy traktować jako postępującą konfesjonalizację małopolskich reformowanych.

Tak zreorganizowana - albo zorganizowana od początku - po $1595 \mathrm{r}$. Jednota Małopolska miała już charakter zdecydowanie prezbiteriański. Podstawową jej jednostką była parafia (zbór). Nad jej prawidłowym funkcjonowaniem czuwali pastor oraz lokalni patroni, biorący, jako starsi, udział w regularnych synodach dystryktowych. Te ostatnie, choć nazywano „synodami”, należy postrzegać jako odpowiednik holenderskiego classis, szkockiego prezbiteratu czy genewskiego konsystorza. Znów rację mają Ptaszyński i Liedke, gdy kwestionują konfrontowanie zapisów synodów prowincjalnych z XVI w. z zapisami synodów dystryktowych z XVII w. Mówimy bowiem o zupełnie różnych ciałach decyzyjnych: to tak jakby porównywać obrady sejmu i obrady rady gminy pod względem ważkości zagadnień.

Właśnie na poziomie dystryktów widzimy powolne kształtowanie się i występowanie w Jednocie Małopolskiej funkcji konsystorza. Obok seniora i dwóch konseniorów duchownych sprawowali ją szczególnie wpływowi patroni świeccy, zawsze w większej liczbie niż seniorzy duchowni. Do ich obowiązków należało: egzekwowanie dyscypliny kościelnej, wizytowanie parafii, rozsądzanie sporów między dość często kłócącymi się wiernym i duchownymi. O tym, że powinniśmy postrzegać synody dystryktowe jako odpowiednik classis, prezbiteratów czy konsystorza, przekonują właśnie słusznie przypomniane przez Ptaszyńskiego „sesje prywatne”, np. w dystrykcie krakowskim i sandomierskim ${ }^{101}$. W dystrykcie lubelskim od 1581 r. nazywa się to krótko, acz znamiennie „odprawowaniem dyscypliny”. Jej „odprawowanie” poprzedzało zazwyczaj sprawowanie sakramentu Wieczerzy Pańskiej, po której następowały obrady całego dystryktu ${ }^{102}$. Świadectwem tego są teksty źródłowe, przywołany wyżej

99 Por. H. Gmiterek, Franciszek Stankar Mtodszy (1562-1621), w: PSB, t. 42 (2003), s. $163-164$.

100 Por. K. Bem, From many different sources, s. 109-115.

101 Por. M. Ptaszyński, op. cit., s. 221.

102 Por. ASR III, s. 45, 103, 179, 207, 212, 201, 223, 234, 249, 264, 272, 280, 293, 296, 304, 314, 325, 350, 359, 370, 385, 408, 415, 426, 436, 447, 538. 
ustęp dystryktu chęcińskiego z 1629 r. czy cytowany niżej fragment postanowień lubelskiego synodu dystryktowego w Bełżycach w 1609 roku: „Tam po rannym nabożeństwie zasiadwszy bracia [ministrowie] i seniorowie [świeccy] dyscyplinę odprawowali, wglądając okiem trzeźwym tak w naukę, jako i w obyczaje ministrów, gdzie z łaski miłego Boga nic się takiego nie stało, co by miało zgorszyć kościół Boży" ${ }^{103}$.

Trzy lata później ten sam dystrykt na synodzie w Lublinie (1612) stwierdził: „W sobotę pierwsza była sesja [...]. Tamże o dyscyplinie namowa był, która acz w kościele miłego Boga zawsze była i jest zachowana, tak się jej jednak stało potwierdzenie, aby w każdym zborze pilnie, taki między bracią ministrami, jako i między pany patrony przestrzegana, a żeby się z imm. i z słuchaczów w swym zborze na nie podpisał i onej się poddawał" 104 .

Doprawdy, trudno o bardziej klarowne opisanie znaczenia dyscypliny kościelnej dla kościoła reformowanego, nie tylko na poziomie parafii, ale i dystryktu! Choć w Jednocie Małopolskiej nigdy formalnie nie wykształciło się stałe ciało na wzór litewskiej Rady Kuratorów, to jednak należy postrzegać jej synody dystryktowe nie jako klasyczne synody, ale raczej jako odpowiedniki genewskiego konsystorza, szkockiego prezbiteriatu czy holenderskiej classis.

Oprócz synodów dystryktowych, starsi (prezbitrzy) z poszczególnych dystryktów Jednoty Małopolskiej zbierali się na zwoływanych z różną regularnością synodach prowincjalnych, gdzie też podejmowano najważniejsze decyzje dla tej prowincji kościelnej. Również tutaj widać wyraźnie istnienie systemu prezbiterialnego dzięki obecności superintendenta i świeckich seniorów prowincjalnych, a także innych duchownych i patronów (starszych świeckich). Jednota Małopolska utrzymała, co prawda, funkcję generalnego superintendenta, ale nie można w tym fakcie widzieć, moim zdaniem, przejawów ustroju episkopalnego. Superintendenci byli wybierani na roczną, a od 1608 r. - na trzyletnią kadencję, czego skrupulatnie przestrzegano w latach $1598-1608^{105}$. Dopiero Franciszek Stankar młodszy był superintendentem, który funkcję tę sprawował od 1608 r. aż do śmierci, lecz i on był wybierany co trzy lata. O tym, że nie była to funkcja niezbędna i ważna dla kościoła, świadczy fakt, że

103 Ibidem, s. 280.

104 Ibidem, s. 325.

105 Por. ibidem, s. 292, 532. 
po jego śmierci w $1621 \mathrm{r}$. nie była ona obsadzona przez trzy lata. Jego następca, Jan Grzybowski, sprawował ją do 1629 r., po czym na własną prośbę zrezygnował i funkcję tę powierzono, znów na trzyletnią kadencję, Tomaszowi Węgierskiemu ${ }^{106}$.

$\mathrm{Na}$ koniec warto też zwrócić uwagę, iż - w przeciwieństwie do Jednoty Litewskiej - w Jednocie Małopolskiej synodom, zarówno dystryktowym, jak i prowincjalnym, od początku przewodniczył zawsze świecki członek kościoła. I choć Jednota Małopolska jako taka musiała dokonać najmniejszych zmian organizacyjno-terminologicznych po synodzie we Włodawie w 1634 r., to jednak wśród wszystkich trzech kościołów była ona kościołem o najsłabszej pozycji duchownych, co było efektem szesnastowiecznej schizmy ariańskiej oraz braku stałej siedziby kościoła, na wzór wielkopolskiego Ostroroga i Leszna albo litewskiego Wilna. Nie zmieniła tego stanu rzeczy w żaden sposób instytucja duchownego generalnego superintendenta.

Poniżej za pomocą Tabeli nr 1 nieco zwięźlej i jaśniej przedstawiam propozycję, jak w kontekście kościołów Szkocji czy Niderlandów widzieć prezbiteriańską organizację Jednoty Małopolskiej od roku 1570.

Tabela 1

\begin{tabular}{|l|l|l|}
\hline \multirow{2}{*}{ SZKOCJA } & & JEDNOTA \\
& NIDERLANDY & MAEOPOLSKA \\
\hline Zgromadzenie Generalne & Synod Narodowy & Synod Generalny \\
Zbierał się co rok od & Zebrał się w roku 1571, & Zebrał się w roku 1576, \\
1560 r. z przerwami & $1576,1584,1618$ & $1578,1583,1595,1634$ \\
w latach 1619-37, & & \\
$1653-90$ & Synody Prowincjalne & Synody Prowincjalne \\
\cline { 2 - 3 } $\begin{array}{l}\text { Prezbiterat } \\
\text { W jego skład wchodzą: }\end{array}$ & Wlassis & Synody Dystryktowe \\
starsi (presbyters) & starsi (ouderlings) & W jego skład wchodzą: \\
duchowni i świeccy & duchowni i świeccy & i seniorzy duchownitryktowi \\
\hline Parafia & Parafia & Parafia \\
Organ wykonawczy: & Organ wykonawczy: & Organ wykonawczy: \\
Kirk Session & Konsystorz parafialny & pastor i patrones loci \\
\hline
\end{tabular}

106 Por. ibidem, s. 531-532. 
Warto tutaj zwrócić uwagę, że Szkocja była w zasadzie jedynym krajem, gdzie regularnie zwoływano Zgromadzenia Generalne, czyli odpowiednik polskich Synodów Generalnych czy niderlandzkiego Synodu Narodowego.

Konkludując, Jednota Małopolska po efemerycznym flircie z systemem episkopalnym na wzór Jednoty Braci Czeskich (1554-1557), wraz z upływem XVI w. stawała się kościołem coraz bardziej prezbiteriańskim $\mathrm{w}$ formie. Proces ten uległ czasowemu spowolnieniu po rozłamie na Zbór Większy i Mniejszy w roku 1562. Jednak po 1570 r., a w szczególności po 1595 r., ustrój Jednoty Małopolskiej ewoluował w stronę ustroju prezbiteriańskiego. Za władzę i dyscyplinę kościelną odpowiadali prezbitrzy, zwani tutaj seniorami świeckimi i duchownymi. Wykonywali ją zazwyczaj podczas synodów dystryktowych - małopolskim odpowiedniku szkockich prezbiteratów, holenderskich classis czy genewskiego konsystorza. Ważniejsze decyzje podejmowano podczas większego zgromadzenia starszych (seniorów), czyli na zwoływanych z różną regularnością synodach prowincjonalnych. System prezbiteriański funkcjonował po 1595 r., mimo wskrzeszenia i utrzymania funkcji superintendenta generalnego.

4.3. Jednota Litewska

W przeciwieństwie do swoich sióstr w Wielkopolsce i Małopolsce, Jednota Litewska od samego początku swego istnienia znajdowała się w wyjątkowej sytuacji polityczno-prawnej. Miała osobowość prawną, mimo tumultów jej siedzibą było Wilno, a stałe wsparcie sześciu pokoleń potężnego rodu Radziwiłłów zapewniło jej stabilizację nieznaną Jednotom w Koronie ${ }^{107}$. Świadczy o tym fakt, iż Jednota Litewska zwoływała synody prowincjalne z regularnością (od 1613 r. odbywały się one zawsze w Wilnie), o jakiej pozostałe dwie Jednoty mogły tylko marzyć. Owa zbieżność pomiędzy stabilizacją prawną a organizacyjną kościoła nie jest przypadkowa.

Jak słusznie zwracali uwagę Ptaszyński oraz Petkunas, Jednota Litewska od samego początku utrzymywała ścisłe związki z kościołami reformowanymi na zachodzie Europy, co zaowocowało nie tylko wyjątkową,

107 Jak dotąd brakuje porównania ewangelickiego patronatu rodów Radziwiłłów i Leszczyńskich, którzy należeli do wyznawców Jednoty Braci Czeskich przez pięć pokoleń, ale ich patronat koncentrował się między Wielkopolską (Leszno) a Małopolską (Baranów Sandomierski). 
jak na polskie warunki, jednolitością liturgiczną, ale także znalazło odzwierciedlenie w ustroju kościelnym.

Pierwszym superintendentem zborów litewskich był Szymon Zacjusz, wybrany na ten urząd w roku $1557^{108}$. Zbieżność daty podjęcia tej decyzji oraz nazwy tej funkcji z jej małopolskim odpowiednikiem jest znamienna. Gdy kościół reformowany na Litwie rozwinął się na tyle, że trzeba było podzielić go na dwie prowincje, wyodrębniono dystrykty wileński z Zacjuszem oraz podlaski z Wędrogowskim jako superintendentami. W 1595 r. dokonano kolejnej reorganizacji, dzieląc Jednotę Litewską na sześć dystryktów. Każdy miał własnego superintendenta i żaden z nich nie był nadrzędny w stosunku do drugiego, dlatego aż do synodu we Włodawie Jednota Litewska nie znała urzędu superintendenta generalnego ${ }^{109}$.

Początkowo superintendenci razem ze świeckim dyrektorem przewodzili obradom synodów, lecz, co znamienne, w pierwszej kolejności podawano imię i nazwisko dyrektora świeckiego. Jednak w 1618 r. tę praktykę zniesiono i od tej pory synodami kierowali już wyłącznie świeccy (na wzór Małopolski) ${ }^{110}$. W 1612 r., oprócz ustalenia, że każdy dystrykt ma mieć swojego superintendenta i konseniora, zadbano o element świecki, podkreślając, że oprócz superintendenta $\mathrm{w}$ dystrykcie potrzebny jest dystryktowy senior świecki ${ }^{111}$. I choć w przeciwieństwie do Małopolski na poziomie dystryktu zmiana ta wpływała na przewagę czynnika kościelnego nad świeckim, to trzeba pamiętać, że Jednota miała w tym samym okresie także świeckich seniorów prowincjalnych, o Radziwiłłach nie wspominając, co skutecznie równoważyło owe dysproporcje. W $1614 \mathrm{r}$. synod wybrał sześciu superintendentów dla sześciu dystryktów, ale także aktora zborowego, jedenastu seniorów szlacheckich i jedenastu seniorów stanu mieszczańskiego. Nie wybrano konseniorów, a zatem proporcja świeckich do duchownych wynosiła prawie 4:1, jak na zachodzie Europy czy nawet w Jednocie Małopolskiej ${ }^{112}$.

108 Por. W. Budka, Szymon Zacius, pierwszy superintendent zborów litewskich, RwP, 1922, 2, s. 288-293.

109 Por. M. Liedke, op. cit., s. 360.

110 Por. SJL, s. 45; H. Gmiterek, Bracia czescy a kalwini w Rzeczypospolitej. Potowa XVI-potowa XVII w., Wydawnictwo UMCS, Lublin 1987, s. 164; M. Kosman, Reformacja i Kontrreformacja $w$ Wielkim Księstwie Litewskim w świetle propagandy wyznaniowej, Ossolineum, Wrocław 1973, s. 242.

111 Por. SJL, s. 7.

112 Por. ibidem, s. 24-26. 
Również pod względem pozycji w kościele wileńscy i podlascy superintendenci przypominali bardziej swoich małopolskich niż wielkopolskich kolegów: ich pozycja nie była wysoka. Gdy Mikołaj Radziwiłł Czarny opowiedział się za arianizmem, a Zacjusz śmiał mu się sprzeciwić, Radziwiłł zwyczajnie usunął go z urzędu. Nawet gdy po synodzie we Włodawie Jednota Litewska dostosowała wreszcie swoje nazewnictwo kościelne do tego z Korony: superintendentów dystryktowych zastąpili seniorzy dystryktowi i powołano superintendenta generalnego, to nie była to zmiana radykalna. Nowy superintendent miał krótką kadencję (jeden rok) i trudno na tej podstawie widzieć w ustroju Jednoty system episkopalny. Co więcej, w ustanawiającym go kanonie wyraźnie podkreślono jego równość z kolegami w urzędzie, także ze świeckimi aktorami zborowymi: „A on z kolegami i patronami i aktorami zborów W[ielkiego] Ks[ięs]twa Lit[ewskie]go, ile in gravioribus znosić się ma, bez ich dołożenia nic privato arbitrio nie czyniąc" 113 .

Konsekwencją spokojnie i regularnie zwoływanych w Jednocie Litewskiej synodów była wyjątkowa w Rzeczypospolitej stabilizacja ustrojowa, ponieważ Jednota ta jako jedyna w Polsce powołała stały odpowiednik genewskiego konsystorza. Marzena Liedke zaproponowała, by wspominane np. w 1612 r. „Małe Zgromadzenie” potraktować właśnie jako konsystorz albo jego zalążek ${ }^{114}$. Ze stanowiskiem tym nie zgodził się Ptaszyński, który uważa, że konsystorzem była powołana w 1636 r. Rada Kuratorów ${ }^{115}$. Tymczasem, moim zdaniem, oboje mają rację.

Jednota Litewska w pierwszym okresie funkcjonowania, podobnie jak Jednota Małopolska, nie miała stałych władz oprócz superintendentów i seniorów świeckich, dlatego dyscyplina kościelna musiała być sprawowana przy okazji synodów dystryktowych albo regularnie zwoływanych synodów prowincjalnych. Ptaszyński ma rację, gdy wskazuje na paralele między litewskim „Małym Zgromadzeniem” a małopolskim „sesjum privatum”. Ja dodałbym do tego lubelskie „odprawianie dyscypliny”. To, że w 1614 r. Litwini nazwali to „sądami”, wcale nie osłabia tej tezy, ale ją wzmacnia. Konsystorz w zakresie kościelnej dyscypliny jest bowiem

\footnotetext{
113 ASR V, s. 163-164.

114 Por. M. Liedke, op. cit., s. 362.

115 Por. M. Ptaszyński, op. cit., s. 220-222.
} 
sądem, od którego decyzji można się było odwołać do synodu, czyli do zgromadzenia plenarnego prezbitrów (procedura ta obowiązuje również dzisiaj w Kościele Szkocji i w Kościele Ewangelicko-Reformowanym w Rzeczypospolitej Polskiej).

Zasadnicza różnica między litewską a małopolską czy wielkopolską Jednotą w XVII w. polegała jednak na tym, iż ta pierwsza właśnie w 1636 r., realizując postanowienia synodu we Włodawie, powołała stały konsystorz - Radę Kuratorów złożoną z sześciu superintendentów dystryktowych oraz sześciu świeckich, co - biorąc pod uwagę istnienie aktora zborowego - gwarantowało przewagę czynnika świeckiego w Jednocie. Nic dziwnego, że wraz z ustanowieniem Rady Kuratorów zanikają sesje prywatne ${ }^{116}$. Zauważyć także trzeba, że chociaż pojawiła się funkcja superintendenta generalnego, to zarówno jego kompetencje, jak i kadencja, pozwalają odrzucić tezę o ustroju synodalno-episkopalnym.

Maciej Ptaszyński proponuje określać Jednotę jako kościół krajowy, podobny do tych w niektórych państwach niemieckich. Jego teza jest bardzo interesująca, ale problematyczna ${ }^{117}$. Krzysztof II Radziwiłł był ostatnim z rodu tak bardzo zaangażowanym w działalność i życie Jednoty. Tego samego nie można powiedzieć o jego synu Januszu i bratanku Bogusławie. Ten ostatni, choć bardzo przywiązany do Jednoty i kalwinizmu, miał inne sprawy na głowie. Badanie modelu i systemu ustrojowego na podstawie jednego i to de facto ostatniego „władcy” budzi wątpliwości. Ciekawsze byłoby porównanie patronatu Radziwiłłów nad kościołem reformowanym w XVI i XVII w. z patronatem rodu Leszczyńskich (w Koronie) oraz z podobnymi sytuacjami na Węgrzech (rody Batorych) czy we Francji (rodu de La Tour d'Auvergne w księstwie de Boullion czy rodu de la Trémoille w księstwie de Thouars), a więc $\mathrm{w}$ krajach, gdzie wyznaniem panującym pozostał katolicyzm, ale gdzie możne rodziny wspierały kalwinizm w swoich posiadłościach w podobnym okresie (połowa XVI-połowa XVII w.) albo do konwersji, albo do wygaśnięcia rodu.

Ustrój Jednoty Litewskiej, Małopolskiej i Kościoła Szkocji staram się przedstawić w Tabeli nr 2.

116 I na odwrót - w Małopolsce, gdzie do powołania stałego konsystorza nigdy nie doszło, sesje prywatne i „odprawowanie dyscypliny” trwało przez cały XVII w.

117 Por. M. Ptaszyński, op. cit., s. 222-223. 
Tabela 2

\begin{tabular}{|l|l|l|}
\hline \multirow{2}{*}{ SZKOCJA } & & JEDNOTA \\
\hline Zgromadzenie Generalne & JEDNOTA LITEWSKA & MAEOPOLSKA \\
Zbierało się raz w roku & Zebrał się w roku 1576, & \\
od 1560 r. z przerwami & $1578,1583,1595,1634$ & \\
\cline { 2 - 3 } w latach 1619-1637 & Synod Prowincjalny & \\
i 1653-1690 & Zbierał się raz w roku & \\
& w latach 1611-1637 & \\
\hline Prezbiterat & Mate Zgromadzenie (do & Synody Dystryktowe \\
W jego skład wchodzą: & 1636 r.) & W jego skład wchodzą: \\
starsi (presbyters) & Rada Kuratorów (od & seniorzy duchowni \\
duchowni i świeccy & 1636 r.) & i seniorzy dystryktowi \\
& W jej skład wchodzą: & \\
starsi (seniorzy) & duchowni i świeccy & \\
\hline Parafia & Parafia & Parafia \\
Organ wykonawczy: & Organ wykonawczy: & $\begin{array}{l}\text { Organ wykonawczy: } \\
\text { Kastor i patrones loci }\end{array}$ \\
\hline
\end{tabular}

5. Podsumowanie

Proponuję, by w dyskusji nad ustrojami polskich Jednot zrezygnować z: poszukiwania za wszelką cenę unikalności polskich kościołów, tworzenia neologizmów na nazwanie określonych form ustroju (np. synodalno-prezbiterialny, synodalno-episkopalny itd.) oraz doszukiwania się już w XVI w. „irenizmu” polskich ewangelików. Zamiast tego postuluję, by na kształtowanie się polskich Jednot ewangelickich patrzeć w szerszym kontekście reformacji i procesów konfesjonalizacji zachodzących od połowy XVI do połowy XVII w. nie tylko na zachodzie Europy, ale także w sąsiednich Czechach i na Węgrzech.

Jednota Wielkopolska miała początkowo osobny, episkopalny ustrój i naukę, Jednota Małopolska rozpoczęła od kongregacjonizmu, Jednota Litewska zaś - od systemu prezbiterialnego. Wraz z upływem XVI stulecia, a w szczególności po 1595 r., możemy obserwować upodabnianie się do siebie nawzajem trzech Jednot, zarówno na płaszczyźnie teologicznej, liturgicznej, jak i organizacyjnej. Przejawiało się to we wzmożonym nacisku na 
karność kościelną i jej przestrzeganie w kościołach, ale także w postępującej prezbiterianizacji w organizacji Jednot. Proces ten, przebiegający w różnym tempie i z różną intensywnością, przypieczętował synod we Włodawie. Proces ten pozostawił również różne lokalne odrębności: w Jednocie Wielkopolskiej - utrzymanie dwóch dożywotnich seniorów duchownych ordynowanych przez nakładanie rąk i przekazujących sukcesję apostolską; w Jednocie Litewskiej - istnienie od 1636 r. stałego konsystorza zwanego Radą Kuratorów i superintendenta generalnego, wybieranego na jeden rok i ordynowanego poprzez podanie ręki. W Małopolsce zmiany były najmniejsze: zachowane zostało stanowisko superintendenta, a funkcje konsystorza sprawowały synody dystryktowe.

\section{The polity of the Reformed Church in the Commonwealth of Two Nations from the mid $16^{\text {th }}$ to the mid $17^{\text {th }}$ centuries}

The article looks at the polity of the three Reformed Churches in the Commonwealth of the Two Nations in the context of the Second Reformation. The author argues that the three churches began with initially very different ecclesiastical polities. The Czech Brethren Church (Jednota Braci Czeskich) in Greater Poland had an Episcopal structure with the bishops (called "seniors") making all the decisions for the church. The Lesser Polish Brethren (Jednota Matopolska) began as a highly decentralized church, resembling a de facto congregationalism. Finally, the Lithuanian Brethren (Jednota Litewska) was from the onset a church with a classical Presbyterian polity. With the passage of time and due to many factors all three churches began to resemble each other more and more and moving towards the Presbyterian polity. It was embraced by the Lesser Poland Reformed from the 1590s onwards, and the Brethren Church after 1608 . This process - paralleled by a liturgical and organizational uniformity - culminated in the Synod of Włodawa (1634) when the Reformed of all three provinces settled on a Presbyterian polity for all three churches, with minor local variations. While all the churches retained the functions of superintendents or seniors, the mere fact of their existence or competence is not enough to suggest an Episcopal polity for any of three churches. 